\title{
The Development Mode of the World-class Scientific and Technical Journals-A Case Study of Nature and Science
}

\author{
Feiyang Liu ${ }^{1}$, Jingxue Lai ${ }^{2}$, Hong Shui ${ }^{1}$, Li Zhang ${ }^{2}$ and Li Zhang ${ }^{1, *}$ \\ ${ }^{I}$ Editorial Department, University of Electronic Science and Technology of China, Chengdu, Sichuan 610054, China; \\ ${ }^{2}$ School of Electronic Science and Engineering, University of Electronic Science and Technology of China, Chengdu, \\ Sichuan 611731, China \\ *Corresponding author: Li Zhang. leezhang@uestc.edu.cn
}

\begin{abstract}
Based on the analysis of the basic situation and development of the world-class scientific and technical journals, Nature and Science, this paper used bibliometrics to explore the development model and construction path of Nature and Science from 3 aspects, including the journal data, journal column structure design and journal brand marketing. From the above analysis, this paper brought up three ways to provide references for the development of domestic sci-tech journals, including improving the academic quality of journals, enriching the non-academic columns to be more attractive, and focusing on the brand itself in order to promote its connotative development.
\end{abstract}

Keywords: world-class scientific and technical journal, bibliometrics, development mode, academic quality, non-academic column, brand building

\section{INTRODUCTION}

Nowadays, more and more journals focus on specific areas. But as the world-class sci-tech journals, Nature and Science are still the most outstanding interdisciplinary ones in the world. The experiences that China's sci-tech journals can learn from them are the main topics in this paper.

In the history of the early stage of the two journals' establishment, Nature and Science both got support from the specific scientists and academic groups. Such great support ensured the quantity and quality of the thesis. Therefore, the authoritative status of these scientific and technological journals was established. With the development for over 150 years, the two journals not only overcame the difficult period at the beginning, but also survived in the World War I and World War II, becoming the most outstanding world-class scientific and technological academic journals.

The first issue of Nature was published on 4 November 1869, while the first one of Science was published on 3 July 1880 [1]. Many journals which were published earlier than them in science had failed eventually. While the valuable success that Nature and Science have grew out of the social and scientific conditions under which it was founded[2] — driven by the vision of strong characteristics, forging ahead when the odds seemed against them are precious experience for us. Nature and Science, above all, become survivors.
With the development of globalization, the world is becoming more and more international. Therefore, the internationalization has become one of the standards to evaluate the excellent sci-tech journals. For Nature and Science, the number of publishing countries has been increasing a lot since last century, from less than 80 countries in 1975 1979 to more than 150 countries today[3]. We can see the articles published in the two journals cover an increasingly large field from all over the world and that the internationalization is getting better than ever before.

\section{MARKETING POSITION OF NATURE AND SCIENCE}

Nature's mission statement: Firstly, it serves scientists through prompt publication of significant advances in any branch of science, and provides a forum for the reporting and discussion of news and issues concerning science. Secondly, it ensures that the results of science can be rapidly disseminated to the public throughout the world and create a fashion that conveys their high attention for knowledge, culture and daily life.

At the second issue, Nature published its vision, aiming to present the major achievements of the scientific research and development to the public, and to add the scientific ideas to not only education and but daily life[4]. Additionally, Nature provides the latest scientific progress to the scientists, creating a platform for them to continuously discuss new scientific issues and exchange their new ideas[5]. The aim and scope at Nature's website states that, "Nature is a weekly international journal 
publishing the finest peer-reviewed research in all fields of Science and technology on the basis of its originality, importance, interdisciplinary interest, timeliness, accessibility, elegance and surprising conclusions. Nature also provides rapid, authoritative, insightful and arresting news and interpretation of topical and coming trends affecting science, scientists and the wider public."[6]

As the Journal of American Association for the Advancement of Science (AAAS), Science has become the core of AAAS and been integrated into the vision of AAAS. As the spokesperson of science and scientists in America, AAAS helps the government to formulate scientific policies, promote the progress of improving science education and increasing diversity of scientific research, and help the public understand the value of science[7]. Promoting the development of science and serving the society have become its target.

By analyzing the vision and mission of the two journals, we can conclude that the position of Nature and Science combines science popularization and academic research. From the very beginning, the readers of the two journals are not limited to scientists, but the whole society[8-9]. Therefore, the two journals also publish nonacademic articles - popular science articles in addition to professional academic papers[10].

\section{SPECIAL DESIGN OF NATURE AND SCIENCE}

Table 1 and Table 2 summarize the columns published on the websites of Science and Nature in 2019, respectively. Except for the large columns like research, which are complete academic papers, other non-academic columns include news, editor's recommendation, article guidance and editorial review, etc. The main purpose of this kind of columns is to let non-professionals understand the cutting-edge scientific news and the purport of academic articles in a more simple and clear way[11]. Moreover, the purpose of publicizing relevant academic articles and expanding the reading range to a certain extent has been achieved. As there are certain requirements for the popular science and academic articles, Science and Nature are more easily accepted and read by readers with different backgrounds compared with other sci-tech journals. No matter what major customers have, they can effectively understand the content of the article. Even nonprofessionals can learn and obtain scientific and technological information from the two journals[12].

Table 1. Columns of Nature

\begin{tabular}{|c|c|c|c|}
\hline \multirow{4}{*}{ This week } & Editorial & \multirow{2}{*}{ Careers } & \multirow{2}{*}{$\begin{array}{l}\text { Column } \\
\mathrm{s}\end{array}$} \\
\hline & World View & & \\
\hline & $\begin{array}{l}\text { Research } \\
\text { Highlights }\end{array}$ & \multirow{2}{*}{ Futures } & \multirow{2}{*}{ Futures } \\
\hline & Seven Days & & \\
\hline \multirow{3}{*}{ Comment } & Comment & \multirow{3}{*}{ Research } & $\begin{array}{c}\text { News \& } \\
\text { Views }\end{array}$ \\
\hline & Books \& Arts & & Articles \\
\hline & Correspondence & & Letters \\
\hline \multirow{2}{*}{$\begin{array}{l}\text { News in } \\
\text { Focus }\end{array}$} & News & \multirow{2}{*}{\multicolumn{2}{|c|}{$\begin{array}{c}\text { Amendments \& } \\
\text { Corrections }\end{array}$}} \\
\hline & Features & & \\
\hline
\end{tabular}

The co-existence of science popularization and academic research contributes a wider readership for Nature and Science and more extensive social influences than other comprehensive sci-tech journals[13]. The wide influence and authority of Nature and Science in the academic areas depends on their positioning of focusing on reporting the significant frontier scientific research results[14].

For sci-tech journals, academic quality is the very foundation of journals. Both journals have reported many important scientific research achievements all the time. For example, Nature reported Darwin's theory of natural selection, the discovery of X-ray, DNA double helix structure, the theory of earth plate motion, reverse transcriptase, the birth of clonal sheep Dolly and other major scientific events. Science has also reported the breakthrough papers on wireless telegraph, the first flight experiment report of Wright brothers, the new discovery of high-temperature superconductor and the new breakthrough in AIDS research[1]. The publication of articles in academic journals is also timely. First of all, sci-tech journals that publish significant scientific research achievements will attract attention and increase their popularity. In turn, scholars with high academic quality manuscripts will be more willing to submit their articles to more well-known sci-tech journals. This is a complementary feedback process. It is precisely the academic quality of articles published by Nature and Science, the strict supervision and examination of academic significance that make today's two journals become the top international journals and enjoy a high discourse power in the academic fields. Beyond that, the two journals will publicize articles published by other great journals, which creates a platform to communicate with other journals.

Table 2. Columns of Science

\begin{tabular}{|c|c|c|c|c|}
\hline \multirow{3}{*}{ Science News } & \multirow{2}{*}{\multicolumn{2}{|c|}{$\begin{array}{c}\text { The week in Science } \\
\text { In Brief }\end{array}$}} & \multirow{3}{*}{ Research } & Research Articles \\
\hline & & & & Reports \\
\hline & \multicolumn{2}{|c|}{ In Depth } & & Review \\
\hline \multirow{4}{*}{$\begin{array}{l}\text { Science's } \\
\text { Compass }\end{array}$} & Editorial & Books ET AL & \multirow{4}{*}{ Recommendation } & \multirow{2}{*}{ Editor's Choice } \\
\hline & Feature & Policy Forum & & \\
\hline & Working Life & Perspectives & & \multirow{2}{*}{$\begin{array}{c}\text { Products \& } \\
\text { Materials }\end{array}$} \\
\hline & Letters & $\begin{array}{l}\text { Technical } \\
\text { comments }\end{array}$ & & \\
\hline
\end{tabular}


By analyzing the column setting of Nature and Science, we can see the humanistic thoughts of the two journals. Readers of them are not limited to scientists only but to teachers, lawyers and officials in government[15]. From the purpose of running the journals, we can see that the positioning of the two journals is not simply to publish scientific research results, but to "provide an exchange platform for scientists" "help scientists develop their own career" and "promote science and serve the society". Both journals have columns focusing on the working environment and life of scientific research practitioners, such as careers and working experience[16]. Since November 1999, Nature has also set up a future column, which mainly publishes short stories of science fiction, whose main purpose is to expand the social impact of science and technology. Not only can these columns directly reflect the profound humanistic care of Nature and Science, but also can be seen from the discipline distribution of high-quality papers published by the two journals. Moreover, millions of dollars are invested to create new columns according to the analysis of readers[17]. The discipline distribution of highly cited articles in the two journals from 1997 to 2018 is extensive. Although most of the articles are scientific subjects, there are also articles in social sciences and humanities chapters[18].

\section{SUGGESTIONS ON COLUMN SETTING OF SCI-TECH PERIODICALS}

There is a long way to go for China's sci-tech journals to develop top journals like Nature and Science. However, we can learn from them by analyzing the successful experience of the two journals.

1) It can be seen from the founding history of the two journals that it is important to guarantee the academic quality and authority of sci-tech journals to have great contributions in the early stage[19]. If excellent contributions are not obtained at the beginning to enhance influence in academic fields, it will be much more difficult to attract high-quality manuscript sources with the history of publishing low-quality papers. Especially at present, when a large number of domestic and foreign sci-tech journals are booming with the development of science and technology, there are more and more choices for high-quality academic papers. Normally researchers are more willing to submit their manuscripts to sci-tech journals with higher quality and stronger academic influence if possible. As a result, the editorial board is very important at the beginning of the establishment of a sci-tech journal[20]. Excellent editorial board members who are willing to help the improvement of the journal will be important resources to promote the development of the journal. Besides, they will also be the direct or indirect sources to contribute to the journal in the early years from the establishment[21].

2) In order to improve the international influence of China's sci-tech journals, it is necessary to establish excellent sci-tech periodicals in English. There are only 500 kinds of English sci-tech journals in China by 2018, accounting for only $6 \%$ of the total sci-tech periodicals. However, the proportion of English sci-tech journals in Germany, is more than 50\%, Japan, more than $20 \%$. Nowadays, English is still a common language for international academic communications. English sci-tech journals are more conducive to attract contributions from outstanding scientists from all over the world, improve the internationalization of journals, and facilitate international academic communications[22].

3 ) To reduce the loss of domestic high-quality manuscripts, it is critical to improve the efficiency of peer review of domestic sci-tech journals, and to publish scientific papers with breakthrough research rapidly. The reason why Nature and Science can keep accumulating academic authority at present, is strongly related to a great deal of breakthrough scientific research achievements published in its history. In the past 20 years China's overall scientific research has been highly developed. In the 1990s, only few Chinese researchers could publish articles on Nature and Science. When it comes to 2018, the number of papers published by Chinese scholars in the two journals has reached the top five in all countries. To keep such excellent achievements and appeal for Chinese scholars to publish articles in domestic sci-tech journals, different efforts are needed, including the political guidance of the government and the hard work of domestic sci-tech journals themselves to improve their comprehensive quality.

4) Enriching the non-academic columns of sci-tech journals is also an important approach to improve the readability and expand the readership. The non-academic column not only achieves the purpose of science popularization, but also facilitates the non-professional scholars and even the public to understand the development of the cutting-edge scientific fields and the professional academic research papers[23]. The academic papers published by the journal, which expands the influence of the journal, can also strengthen the relationship between the journal and readers to establish a reliable connection. However, many sci-tech journals in China only have simple columns where there are only two types of academic research papers and reviews, which leads to the low visibility of journals and lack of audience. The more the number of audiences reduces, the short the circulation of periodicals will be, resulting in the influence not being strengthened. Therefore, we should pay more attention to the column constructions of the sci-tech journals, enrich the structure of journals, pay attention to readers' options, and enhance the readability and humanistic contents of journals.

5) In the age of internet, there are many effective ways like the websites and social medias to broaden the market of journals. But unfortunately, many domestic sci-tech journals don't take the websites and social media seriously. Actually, sometimes only one picture can speak thousands of words. It is easier to draw attention from readers by using appropriate photos. In a word, great journal websites are also more likely to leave people a good impression of professional and high-quality journals. Therefore, China's 
sci-tech journals should think highly of the effect of website and social media.

\section{CONCLUSION}

Through the analysis and discussion of the development model of the world-class journals Nature and Science, we can learn that as comprehensive journals with a nature of full discipline, Nature and Science closely follow the cutting-edge scientific development. In the two journals, molecular biology and genetics account for the highest proportions. In terms of the design in column structure, the core of scientific and technological journals is to provide readers with the latest scientific research results in various disciplines. Besides, columns like Highlights and Science's Compass will give a comment on the future state of scientific research and provide a space for communication between authors and readers. What's more, it is important to focus on the construction of journal branding to attract readers. In this article, the method of bibliometrics is used to analyze and discuss the development of journals. But the loss of collection of journal historical data may lead to incomplete analysis. If there is any opportunity in the future, the writer will have more comprehensive data to explore the development path of first-class journals more detailed.

\section{REFERENCES}

[1] B. Wang, "The trends of science development based on metrical analysis the contents on Nature and Science during the 20th century," Shanxi University, 2013. (In Chinese)

[2] G. Zou, "Major changes in British economic policy in the 1980s," World Economic Papers,1991, pp.35-40.(In Chinese)

[3] Y. Qiao, "Statistics and analysis of total cited frequency of North western Geology from 2001 to 2012," North western Geology, 2014, 47(3), pp.121-125. DOI: http://doi.org/10.3969/j.issn.1009-6248.2014.03.016 (In Chinese)

[4] W. Zhai, "Non-academic columns in Nature: Components, functions, and implications for scientific journals in China," Chinese Journal of Scientific and Technical Periodicals, 2018(12), pp.1183-1191. DOI: http://doi.org/CNKI:SUN:JYKQ.0.2018-12-001 (In Chinese)

[5] Z. Chen and S. Yang, "Management of journal and publishing company: Nature," Library and Information
Service, 2006(3), pp.75-80. DOI: http://doi.org/ 10.3969/j.issn.0252-3116.2006.03.018 (In Chinese)

[6] Y. Li and X. Wang, "Review on science and its enlightenment," Science \& Technology Review, 2002(9), pp.25-27. DOI:

http://doi.org/10.3321/j.issn:1000-7857.2002.09.006 (In Chinese)

[7] Y. Wang, "The successful experience of Science and its enlightenment to Chinese scientific and technological academic journals," Publishing Research, 2004(12), pp.80-83. DOI:

http://doi.org/10.3969/j.issn.1001-9316.2004.12.019 (In Chinese)

[8] X. Wang, "A probe into the centennial American magazine science," China Publishing Journal, 1999(6), pp.57-58. DOI:

http://doi.org/CNKI:SUN:ZGCB.0.1999-06-028 (In Chinese)

[9] S. Zhang, "On the humanistic thoughts of science and the revelation to China," Science and Technology Management Research, 2014(14), pp.246-250. DOI: http://doi.org/10.3969/j.issn.1000-7695.2014.14.050 (In Chinese)

[10] M. Zeng and W. Xu, "Talk about international journal Nature," Journal of Inner Mongolia University for Nationalities, 2005(6), pp.113-116. DOI: http://doi.org/ CNKI: SUN: NMSX.0.2005-06-031 (In Chinese)

[11] Y. Du, "Talking from the publishing house transformation," Chinese Editors Journal, 2004(5), pp.21-22. DOI: http://doi.org/ (In Chinese)

[12] Y. Shi, "Nature's audience orientation: Satisfy readers," Chinese Journal of Scientific and Technical Periodicals, 2003,14(1), pp.79-81. DOI: http://doi.org/ 10.3969/j.issn.1001-7143.2003.01.028 (In Chinese)

[13] X. Liu, J. Chu and J. Zhang, "Characteristics and thoughts on the quality and influence construction of Sci-tech journals in three European countries," Chinese Journal of Scientific and Technical Periodicals, 2014, 25(1), pp.5-9. DOI: http://doi.org/10.3969/j.issn.1001-7143.2014.01.002 (In Chinese)

[14] Z. Wu and X. Su, "The development path and inspiration of Nature," Library and Information, 2015(1), pp.27-37. DOI: http: //doi.org/10.11968/tsygb.1003-6938. 2015005 (In Chinese) 
[15] S. Ye, "Introducing the British journal: Nature," Acta Editologica, 1989, 1(2), pp.111-113. DOI: http://doi.org/ 10.16811/j.cnki.1001-4314.1989.02.014 (In Chinese)

[16] H. Jia and J. Wu, “American academician talks about popularization of science - interview with Albert Bruce, editor-in-chief of Science magazine and former dean of the national academy of sciences," Science News, 2009(24), pp.70-71. DOI: http://doi.org/ (In Chinese)

[17] J. Liu, "Thoughts from Science," Chinese Journal of Scientific and Technical Periodicals, 2000,11(2), pp.131. DOI: http:

//doi.org/10.3969/j.issn.1001-7143.2000.02.03 5 (In Chinese)

[18] K. Kaneiwa, J. Adachi and M. Aoki, “A comparison between the journals nature and science," Science, 1988, 13(3-4), pp.125.DOI:

http://doi.org/10.1007/BF02017179

[19] S. Ren and G. Wu, "Statistical comparison and analysis of papers in Chinese science bulletin and Nature," Acta Editologica, 2000(4), pp.203. DOI: http://doi.org/ CNKI: SUN: BJXB.0.2000-04-008 (In Chinese)
[20] W. Chen, "Comparison between journals of Science bulletin in China and Science in USA," Information Research, 2017(2), pp.20. DOI: http://doi.org/10.3969 /j. issn.1005-8095.2017.02.004 (In Chinese)

[21] Q. Hu, "The concept of running foreign sci-tech periodicals-strengthening readers' awareness," Chinese Journal of Scientific and Technical Periodicals, 2017(2), pp.20. DOI: http://doi.org/10.3969/j.issn.1001-7143.2005. 04.050 (In Chinese)

[22] Y. Zhang, D. Xu and F. Xu, "Bibliometrics comparative research and enlightenment between journal of Science and Nature on the basis of web of Science," Science and Technology Management Research, 2017, 37(15), pp.250. DOI: http://doi.org/10.3969/j.issn.1000-7695.2017.15.037 (In Chinese)

[23] Z. Yu, "Discussion on constitution of core competitive power of top journals and its improvement," Acta Editologica, 2005(5), pp.321. DOI: http://doi.org/ CNKI: SUN: BJXB.0.2005-05-003 (In Chinese) 